WSRC-TR-2003-00517

\title{
Geochemistry of Hydrofluoric Acid in Kaolinitic Soils (U)
}

\author{
Miles Denham \\ Maggie Millings \\ Environmental Sciences and Technology Department \\ Savannah River Technology Center
}

November 2003

Westinghouse Savannah River Company

Savannah River Site

Aiken, SC 29808

Prepared for the U.S. Department of Energy Under Contract No. DE-AC09-96SR18500 
This document was prepared in conjunction with work accomplished under Contract No. DE-AC09-96SR18500 with the U. S. Department of Energy.

\section{DISCLAIMER}

This report was prepared as an account of work sponsored by an agency of the United States Government. Neither the United States Government nor any agency thereof, nor any of their employees, makes any warranty, express or implied, or assumes any legal liability or responsibility for the accuracy, completeness, or usefulness of any information, apparatus, product or process disclosed, or represents that its use would not infringe privately owned rights. Reference herein to any specific commercial product, process or service by trade name, trademark, manufacturer, or otherwise does not necessarily constitute or imply its endorsement, recommendation, or favoring by the United States Government or any agency thereof. The views and opinions of authors expressed herein do not necessarily state or reflect those of the United States Government or any agency thereof.

This report has been reproduced directly from the best available copy.

Available for sale to the public, in paper, from: U.S. Department of Commerce, National Technical Information Service, 5285 Port Royal Road, Springfield, VA 22161, phone: (800) 553-6847, fax: (703) 605-6900

email: orders@ntis.fedworld.gov

online ordering: http://www.ntis.gov/help/index.asp

Available electronically at http://www.osti.gov/bridge

Available for a processing fee to U.S. Department of Energy and its contractors, in paper, from: U.S. Department of Energy, Office of Scientific and Technical Information, P.O. Box 62, Oak Ridge, TN 37831-0062,

phone: (865)576-8401,

fax: (865)576-5728

email: $\underline{\text { reports@ adonis.osti.gov }}$ 
WSRC-TR-2003-00517

\section{Introduction}

This document explores the geochemical reactions likely to occur when hydrofluoric acid is spilled on Savannah River Site (SRS) soil. In particular, we evaluate the potential of environmental damage from a one-time release of concentrated hydrofluoric acid into a trench.

According to interviews with personnel involved, sometime between 1955 and 1960 twenty-eight 55-gallon drums of 50-60\% hydrofluoric acid were disposed in a trench in the Central Shops area. The method of disposal suggests that most of the acid would have been released at the time of burial. The drums were too corroded and fragile to be moved safely. Hence, a trench was dug next to the acid storage area and the drums were pushed into the trench. The trench was backfilled with soil and compacted with a bulldozer. Efforts to locate this trench and obtain samples to assess risk have not been successful. This included a walk down of potential disposal areas with the operator who remembers burying the drums. Based on his recollections and aerial photographs, areas for further investigation were identified. These were evaluated in detail with ground penetrating radar surveys, as well as with trenching and sampling. No evidence of drum disposal or acidic $\mathrm{pH}$ values was found (Friday, WSRC-TR-2003-00522). Therefore, the Soil and Groundwater Closure Projects group requested that we evaluate potential risk by examining the major geochemical interactions expected between hydrofluoric acid and soil.

The geochemical calculations in this report were done with The Geochemist's Workbench ${ }^{\circledR}$. This program uses an extended Debye-Huckel method for calculating activity coefficients. However, the ionic strengths of solutions of 50-60\% hydrofluoric acid in soil can exceed those for which this method can accurately calculate activity coefficients. Thus, some results may have significant uncertainty. For example, at high ionic strengths the extended Debye-Huckel method tends to overestimate activity coefficients. This would result in an underestimation of the amount of kaolinite required to bring hydrofluoric acid to a particular $\mathrm{pH}$. At worst, the amount of kaolinite $\left[\mathrm{Al}_{2} \mathrm{Si}_{2} \mathrm{O}_{5}(\mathrm{OH})_{4}\right]$ required to raise the $\mathrm{pH}$ to 4 may be doubled the amount calculated. This would translate to doubling of the distance that the acid would have to migrate to achieve a $\mathrm{pH}$ of 4 . The level of acceptable uncertainty depends on the objective of the calculations. In this case, the objective is to evaluate whether the hydrofluoric acid is likely to be an environmental concern. For this purpose, the level of uncertainty is probably acceptable. Furthermore, it should be noted that the final solution at $\mathrm{pH}=4.17$ has an ionic strength of about 1.3 molal and is within reasonable limits for the extended Debye-Huckel theorem. This suggests that the conclusions of this report are accurate, but that some of the intermediate steps may have higher uncertainty.

\section{Chemistry of Hydrofluoric Acid}

Though hydrofluoric acid is powerful and highly reactive, it behaves like a weak acid with a $\mathrm{pKa}=3.2$. Thus, below a $\mathrm{pH}$ of 3.2 the dominant species are the fully protonated $\mathrm{HF}^{\mathrm{o}}$ and $\mathrm{H}_{2} \mathrm{~F}_{2}{ }^{\mathrm{o}}$. These dissociate to $\mathrm{F}-$ and $\mathrm{HF}_{2}{ }^{-}$and above $\mathrm{pH}$ of $3.2 \mathrm{~F}$ - is the dominant 
species. Figure 1 shows the variation of hydrogen fluoride speciation with $\mathrm{pH}$. The weak acid behavior of hydrofluoric acid tends to buffer the $\mathrm{pH}$ so that concentrated solutions have a $\mathrm{pH}$ between 0.5 and 1 (Figure 2).

The behavior of hydrofluoric acid in SRS soils is unusual compared with other acids, because of the strong tendency of aluminum and silicon to form aqueous fluoride complexes. Figures 3 and 4 show the behaviors of aluminum and silicon in fluoride solutions. The result of the complexing is enhanced reactivity of soil with hydrofluoric acid, and thus greater capacity for neutralization of the acid.

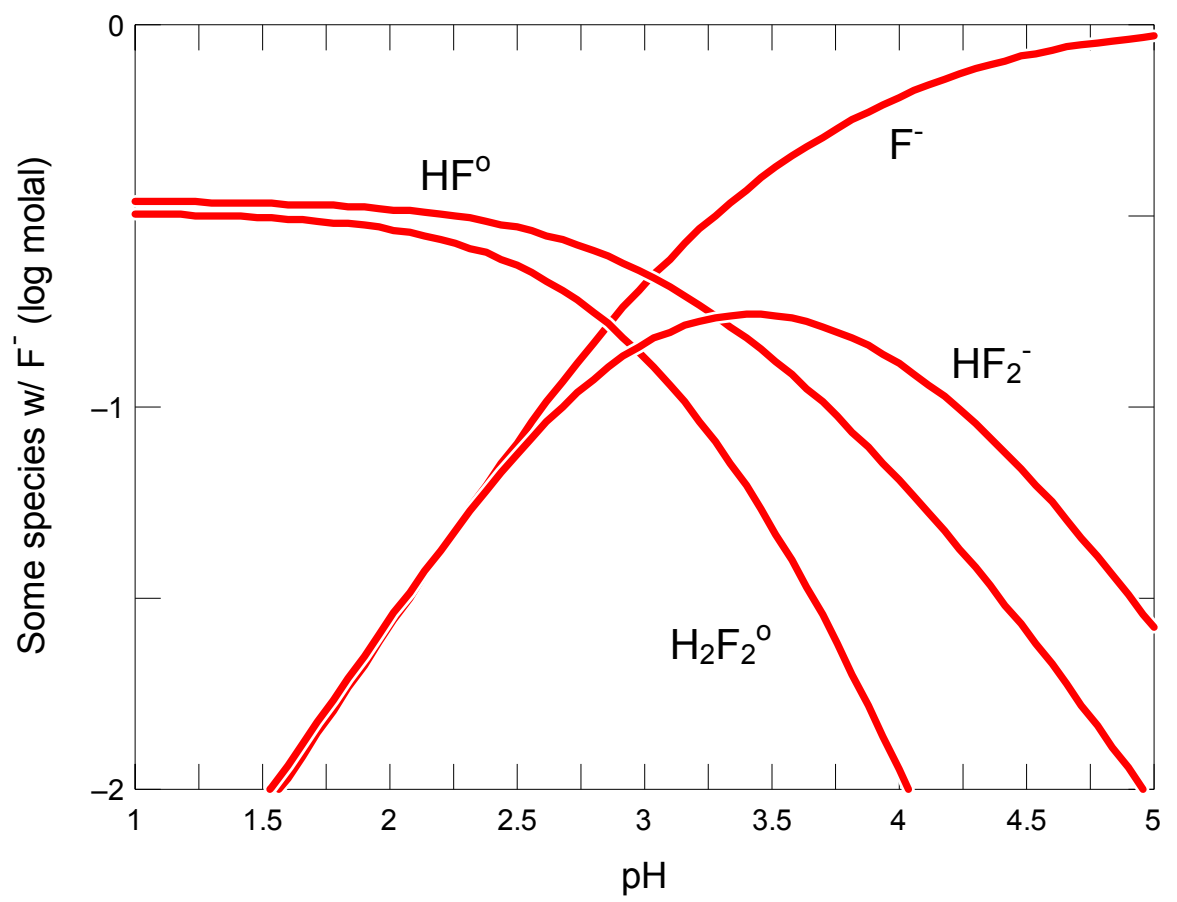

Figure 1: Speciation of fluoride in aqueous solution. 
WSRC-TR-2003-00517

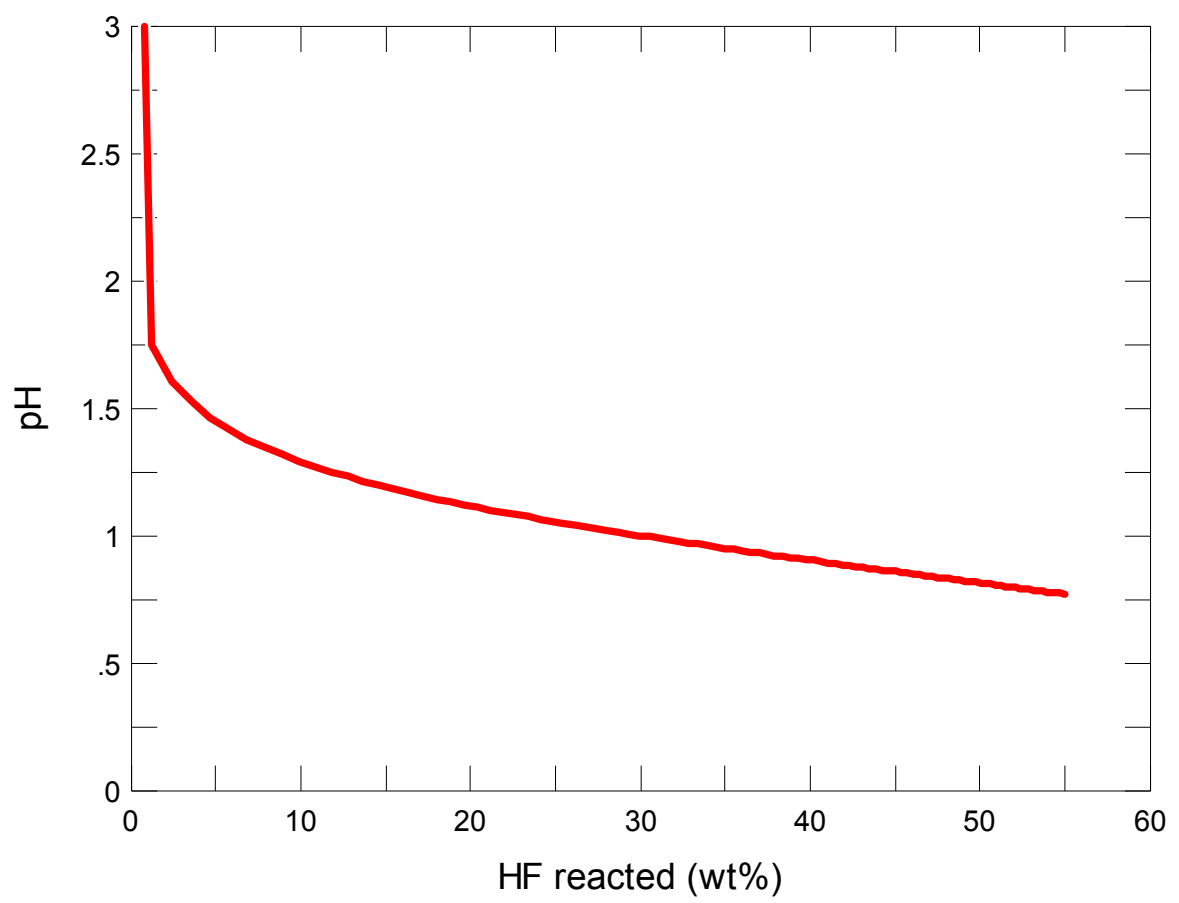

Figure 2: $\mathrm{pH}$ versus concentration of hydrofluoric acid. 
WSRC-TR-2003-00517

\section{Reactions of Hydrofluoric Acid in Soil}

SRS soils are composed primarily of quartz, kaolinite and minor amounts of iron oxides or oxyhydroxides. Quartz reacts slowly with hydrofluoric acid at ambient temperatures and concentrations of iron minerals are generally less than $2 \mathrm{wt} . \%$. Thus, the most prominent reaction is expected to be dissolution of kaolinite. The dominant reaction can take several forms that either release or consume acid, depending upon speciation. For example:

$$
\begin{aligned}
& \mathrm{Al}_{2} \mathrm{Si}_{2} \mathrm{O}_{5}(\mathrm{OH})_{4}+18 \mathrm{HF}^{\mathrm{o}}=2 \mathrm{AlF}_{3}{ }^{\mathrm{o}}+2 \mathrm{SiF}_{6}{ }^{-2}+9 \mathrm{H}_{2} \mathrm{O}+\mathbf{4} \mathbf{H}^{+} \\
& \mathrm{Al}_{2} \mathrm{Si}_{2} \mathrm{O}_{5}(\mathrm{OH})_{4}+18 \mathrm{~F}^{-}+\mathbf{1 4 H}^{+}=2 \mathrm{AlF}_{3}{ }^{\mathrm{o}}+2 \mathrm{SiF}_{6}{ }^{-2}+9 \mathrm{H}_{2} \mathrm{O}
\end{aligned}
$$

Figure 5 shows the curve for titration of 55 wt. \% hydrofluoric acid with kaolinite. The initial $\mathrm{pH}$ is 0.77 and during the early stages of the titration kaolinite dissolution drives the $\mathrm{pH}$ down further. After about $75 \mathrm{~cm}^{3}$ of kaolinite have dissolved, acid consuming reactions become dominant and the $\mathrm{pH}$ rises. Saturation with kaolinite is reached at a $\mathrm{pH}$ of 4.17 after dissolution of approximately $210 \mathrm{~cm}^{3}$. Thus, low $\mathrm{pH}(<2)$ will be maintained for a short distance as hydrofluoric acid migrates through soil, but reaction with kaolinite will elevate $\mathrm{pH}$ to above 4 .

The aqueous species $\mathrm{AlF}_{3}{ }^{\mathrm{o}}$ and $\mathrm{SiF}_{6}{ }^{-2}$, products of the reaction with kaolinite, will persist in groundwater until dilution depletes the fluoride concentration significantly. A plot of saturation indices versus kilograms of dilution water shows the effects of dilution on amorphous silica and gibbsite $\left[\mathrm{Al}(\mathrm{OH})_{3}\right]$ (Figure 6). The groundwater becomes saturated with amorphous silica during the latter stages of reaction with kaolinite and silica will likely precipitate during this time. Silica continues to precipitate during initial dilution, but precipitation ceases after the groundwater has been diluted by a factor of 2 . Gibbsite becomes saturated when the groundwater has been diluted by approximately 5 times. It continues to precipitate past a dilution factor of 10 . This suggests that aluminum may precipitate at the water table, forming a layer enriched in gibbsite or amorphous aluminum hydroxide.

\section{Conceptual Model}

Twenty-eight full 55-gallon drums contain a total liquid volume of 5829 liters or $5.83 \times 10^{6} \mathrm{~cm}^{3}$. If the base of the trench was 12 feet wide and 30 feet long, then the area of the base was $360 \mathrm{ft}^{2}$ or $334,451 \mathrm{~cm}^{2}$. If we assume that all of the acid was spilled during disposal and formed a layer of equal thickness throughout the trench, a $17 \mathrm{~cm}$ thick layer would have formed. At an assumed fractional porosity of 0.25 , one pore volume of the acid in soil would be $68 \mathrm{~cm}$ thick. Based on this, the titration curve for kaolinite in the acid, and assumptions about the amount and reactivity of kaolinite, the $\mathrm{pH}$ of the acid layer can be estimated as it passes through the vadose zone. Figure 7 shows the estimated $\mathrm{pH}$ with depth below the trench. At a depth of $470 \mathrm{~cm}$ the acid solution reaches saturation with kaolinite at a $\mathrm{pH}$ of 4.17. This accounts only for reaction of the acid with kaolinite and does not consider dispersion or dilution in the vadose zone. These processes would 
promote quicker neutralization of the acid. Furthermore, the assumptions in this analysis are generally conservative. It is assumed here that the soil contains $10 \mathrm{wt} . \%$ kaolinite, but only $10 \%$ of this reacts with the passing acid. If porosity were greater than 0.25 (a common occurrence), or the soil were composed of greater than $10 \%$ kaolinite, or more than $10 \%$ of the kaolinite reacted, then the migrating acid layer would reach a $\mathrm{pH}$ of 4.17 at shallower depths.

The potential effect of dilution by rainwater can be illustrated by assuming that all of the acid was released upon disposal of the drums and subsequently mixed with rainfall over the course of 1 year. The 30 year average rainfall is $127 \mathrm{~cm} /$ year (50 inches/year). Mixing of this with the disposed acid yields an 8 wt.\% hydrofluoric acid solution. Figure 5 shows the titration of this solution with kaolinite (dashed line). The $8 \mathrm{wt} . \%$ solution requires reaction with $69 \mathrm{~cm}^{3}$ of kaolinite to achieve saturation at a $\mathrm{pH}$ of 4.94 . This is one third the amount required to titrate the $55 \mathrm{wt} . \%$ solution to a saturation $\mathrm{pH}$ of 4.17 . Thus, given the same assumptions, the diluted solution would migrate one third the distance, $157 \mathrm{~cm}$, before reaching the final $\mathrm{pH}$ of 4.94 .

Other processes that would promote neutralization of the acid are dispersion of clay-sized material and gel formation. Abrupt changes in groundwater chemistry can cause claysized material to disperse and clog pore throats. Likewise, the clay minerals may form pore clogging gels during reaction with hydrofluoric acid. The resulting decrease in permeability would increase the residence time of the acid solution in a given volume, allowing more kaolinite to react.

When the acid solution reaches the water table, substantial dilution will occur and gibbsite may precipitate by the reaction:

$\mathrm{AlF}_{3}{ }^{\mathrm{o}}+3 \mathrm{H}_{2} \mathrm{O}=\mathrm{Al}(\mathrm{OH})_{3}+3 \mathrm{H}^{+}+3 \mathrm{~F}^{-}$

This is an acid producing reaction that tends to counter the effects of dilution on elevating the $\mathrm{pH}$. However, the $\mathrm{pH}$ will be maintained near 5.0 (Figure 8). The dilution calculations (Figure 6) indicate that silica would not be expected to precipitate at the water table.

\section{Summary}

Hydrofluoric acid disposed in a trench in the Central Shops area would have reacted with soil kaolinite to neutralize the $\mathrm{pH}$ to a value of about 4.2. Based on conservative assumptions, this would have occurred within the top $500 \mathrm{~cm}$ of soil. This analysis considers only the reaction of the acid with kaolinite. Other processes such as dilution, dispersion, and clogging of permeability would contribute to neutralization of the acid within a shorter distance.

When the acid solution reached the water table, dilution would have driven the solution to saturation with gibbsite. A resulting layer enriched in aluminum may be the only remnant of the acid disposal identifiable today. However, any such layer would be difficult to identify because of the normally high aluminum concentrations in the soil. 
Subtle textural evidence of shallow soil dissolution may be present, but 40 years of rainfall infiltration may well have erased such evidence.

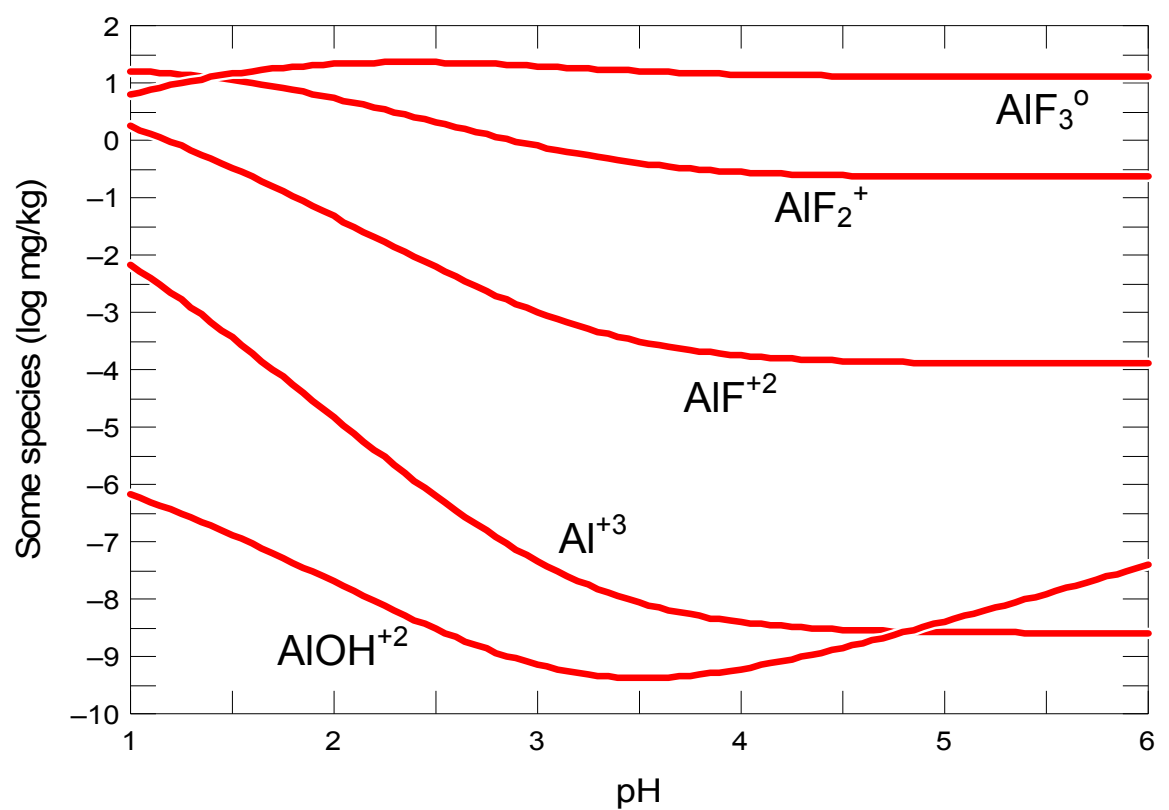

Figure 3: Speciation of aluminum in $100 \mathrm{mg} / \mathrm{L}$ fluoride solution.

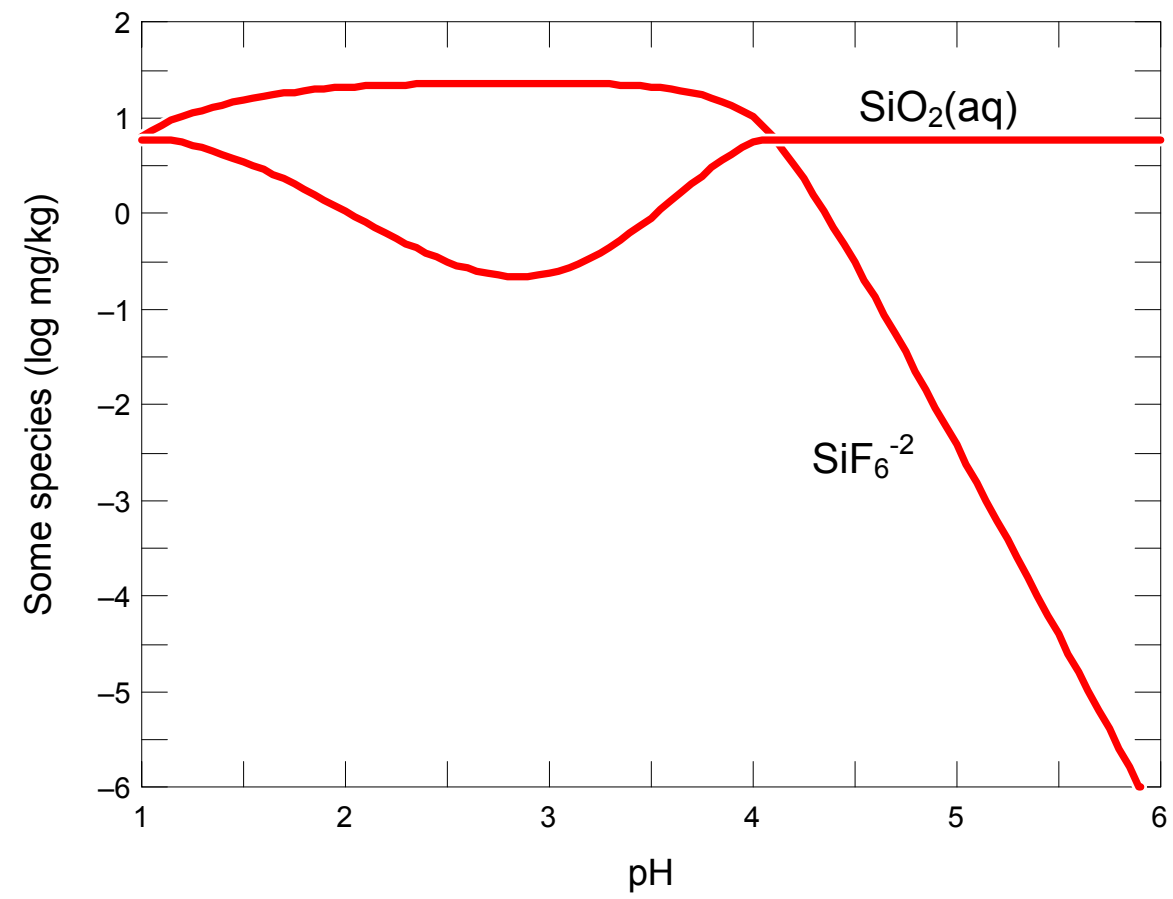

Figure 4: Speciation of silica in $100 \mathrm{mg} / \mathrm{L}$ fluoride solution. 
WSRC-TR-2003-00517

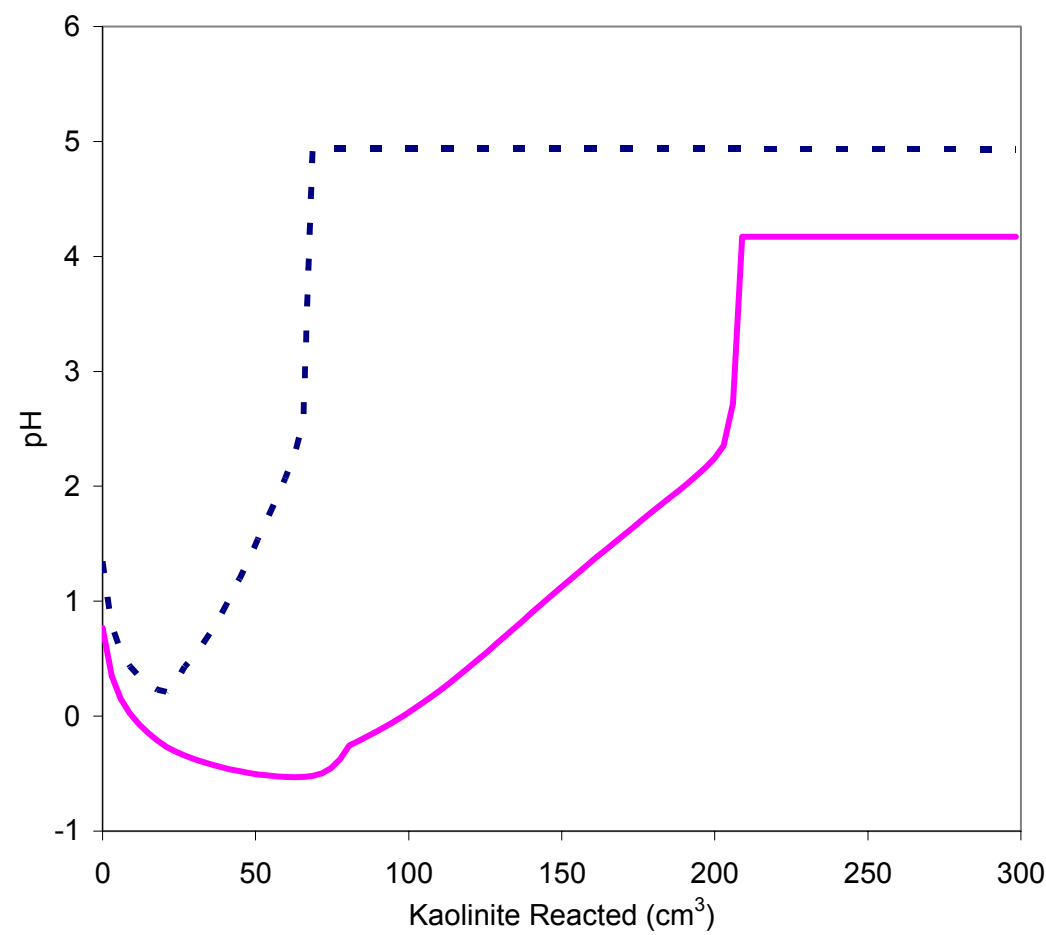

Figure 5: Titration of $1 \mathrm{~kg}$ hydrofluoric acid solution with kaolinite. Solid line is titration of 55 wt.\% HF. Dashed line is titration of 55 wt.\% HF diluted to 8 wt.\%.

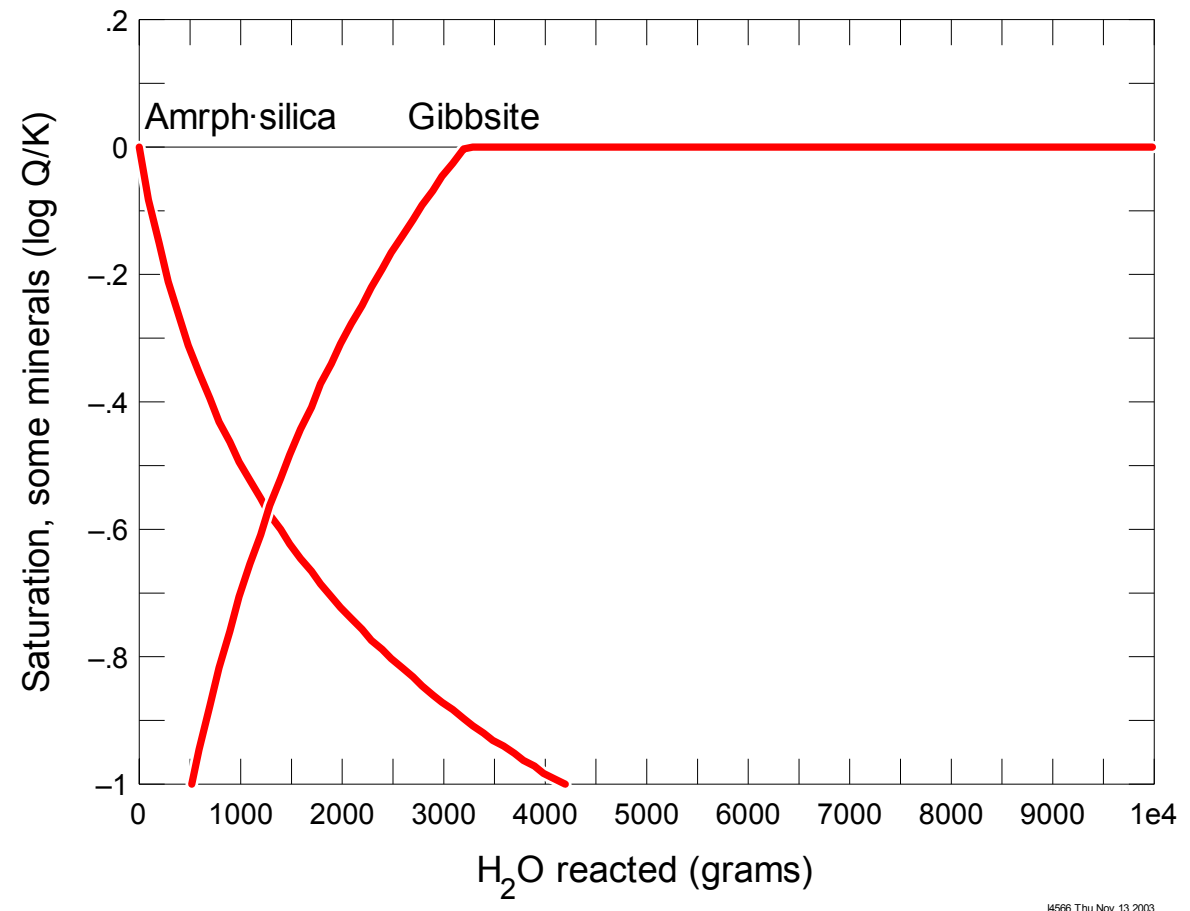

Figure 6: Saturation indices of amorphous silica and gibbsite as dilution proceeds. Saturation occurs at zero. 
WSRC-TR-2003-00517

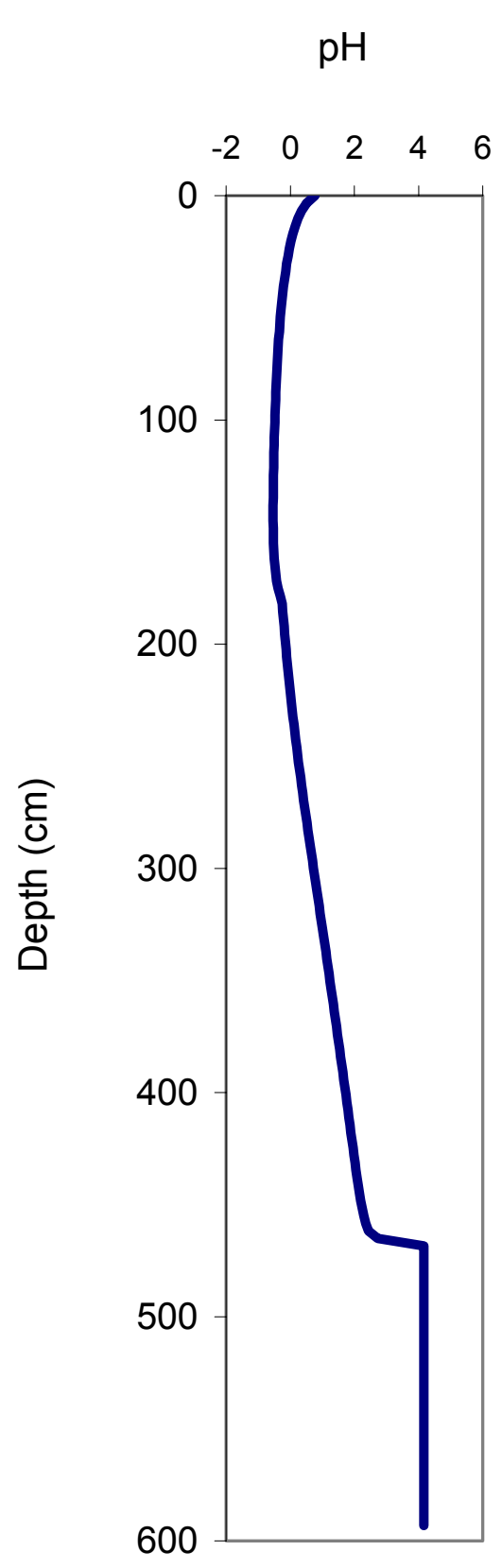

Aqueous $\mathrm{Al}$ and $\mathrm{Si}$

(log $\mathrm{mg} / \mathrm{kg}$ )
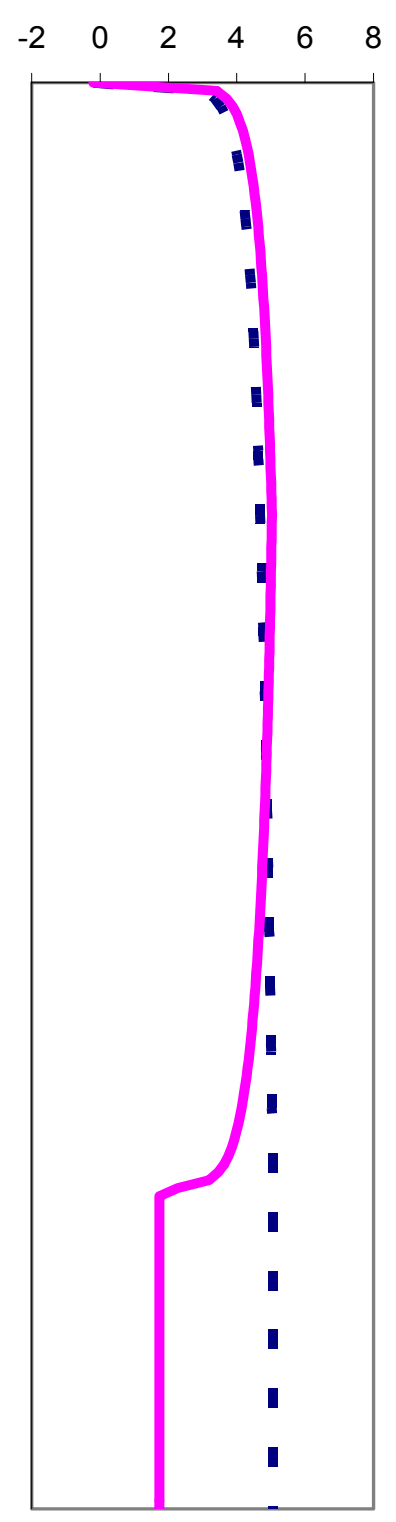

Figure 7: $\mathrm{pH}$, aqueous $\mathrm{Al}$ concentration (dotted line), and aqueous silica concentration (solid line) versus depth below trench base. Assumptions are discussed in text. 
WSRC-TR-2003-00517

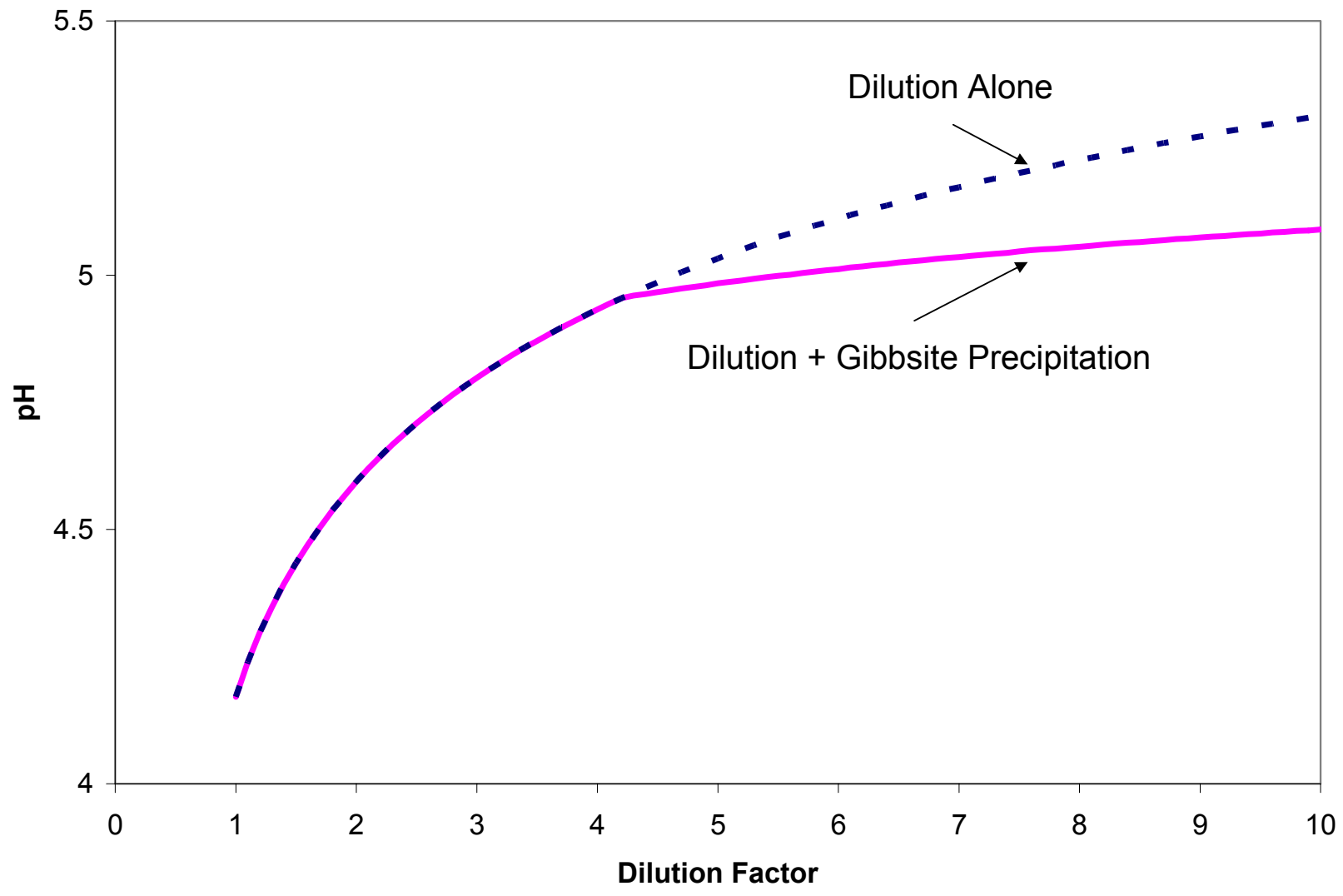

Figure 8: $\mathrm{pH}$ versus dilution factor for dilution alone and dilution plus precipitation of gibbsite. 